Minister of State at the Ministry of Technology, will have his office there.

The Ministry of Technology is to be organized in three main groups-Engineering, Research, and Aviation. The new controllers will be Dr. G. G. Macfarlane (Research) and Mr. Ieuan Maddock (Industrial Technology) (Nature, 213, 645; 1967), while the Aviation section-the largest of the three-will be controlled by Air Marshal Sir Christopher Hartley.

\section{Profession of Physics}

An even more detailed analysis of the structure of professional physics has now been published by the American Institute of Physics, based in part on the information obtained from the National Register (Physics Manpower 1966, American Institute of Physies, $\$ 2 \cdot 50$ ). The survey is particularly informative on the recruitment of physicists at different parts of the education system, and on the immigration into the United States of physicists from elsewhere.

The survey suggests that it is as yet too soon to know what the effect will be of the new physics courses produced by the Physical Science Study Committee on education in physics in the United States. Of those graduating in physics in 1966, only 16 per cent will have followed the PSSC course at high school. In future years, however, the crop should be larger, for it is estimated that in the academic year 1964-65, roughly 50 per cent of high school physics students in the United States were enrolled in a PSSC course. The survey points out that the numbers of physics teachers in high schools have been declining as a fraction of science teachers as a whole, which seems to imply an increase in the numbers of mathematicians and others on high school faculties. In the universities, the Institute of Physics has found that from year to year a smaller fraction of those who enrol for a degree elect to become physics majors at the end of their course. In fact, just over 1 per cent of male entrants to American universities in September 1962 chose to specialize in physics in September 1965, with universities on the north-eastern seaboard producing more physics students than their share.

Allowing for the relatively high rate of drop-out between one year and the next, it is estimated that the number of bachelor degrees in physics will decline from 5,500 or so at present to 4,500 or so by the end of the decade. But, because of the steadily incrcasing tendency for graduates to stay on for postgraduate work, it is expected that the output of higher graduates will gradually increase at least until the 1970s. In practice, just about a half of those graduating in physics seem to stay on for further study. The number of Ph.D. degrees awarded each year in the United States has increased from roughly 490 in $1955-56$ to 983 in 1964-65. By the early seventies there are expected to be about 1,200 Ph.D. graduates each year.

On immigration into the United States, the report points out that roughly 12 per cent $(1,800)$ of physics graduate students in the United States come from abroad and that 69 per cent $(1,280)$ of these foreign students are from Asia. In 1964-65 Europe contributed 211 graduate students in physies to the total. On the employment in the United States of physicists with degrees from foreign universities, it appears that Europe contributes 72 per cent of the total of 1,315 at work in 1964. The United Kingdom contributed 362 of these, West Germany 258, and Canada 137.

\section{$R$ \& $D$ at the R.I.}

"THe richest of all Lords is use" according to Emerson, and Lord Rothschild might have taken this as his text for his Friday evening discourse at the Royal Institution on February 17. His theme, "Research in a Very Big Industry", gave him an opportunity to emphasize the virtues of the operations of monopoly corporations at the frontiers of knowledge, and to comment on the differences between academic and industrial research. Industrial research is more concerned with getting exploitable results than is the academic variety, and its results should ideally have some value and be available when they are wanted. Lord Rothschild felt that these questions are still too far in the background in much academic research. He had, he said, come across cases where work had been going on for years and years without anyone bothering to ask "Is it useful ?". The excuse given for this type of work, that it adds to the sum total of human knowledge, was "trite and inadequate". So far as industry was concerned, it was as well to be wary in assessing the value of research to a company. In general, research does help growth, but the difficulty is to know whether companies with high growth rates favour research because they have a high growth rate or whether it is the research that produces the high growth rate.

\section{False Teeth in Space}

THE view that "Mankind takes his dental problems with him wherever he goes" was the theme of the paper read by B. Lawrence Shalit to the conference on "Planetology and Space Mission Planning" held in New York at the end of 1965, the proceedings of which have now been published by the New York Academy of Sciences (Annals, 140, Art. 1, 1; 1966). Although most of the contributions to the symposium dealt with the potential accomplishments of various rocket systems and the desirability of space missions such as landing on asteroids, Mr. Shalit put forward his plan for dental care in space "to prevent the astronauts from being incapacitated by dental problems and, secondarily, to protect the oral cavity of the individual astronaut from permanent damage of any type during space flight".

At least for short flights, Mr. Shalit believes that it will be possible to correct most dental defects before launching, so that none of the common dental troubles need disqualify people from becoming astronauts. Moreover, Mr. Shalit rejects the notion that it would be simplest "to equip all astronauts with full dentures": not merely would this make mastication less efficient but "the loss would be psychologically upsetting or even unacceptable". He does, however, recommend that before sending men into space, dental surgeons should eliminate non-vital and suspicious teeth, third molars "if, in the opinion of the examiners, this is indicated", the instruction of astronauts in the use of temporary fillings and analgesics, and the careful planning of meals so that starchy items are eaten first. On longer space flights, Mr. Shalit suggests that the potential hazards of dental caries should be minimized by "reduction in frequency of eating", and that astro- 